\title{
Berenika Seryczyńska
}

\section{PEWNA SPOWIEDŹ}

Był ciepły wiosenny dzień. Lekkie powiewy wiatru delikatnie poruszały liśćmi na drzewach rosnących po obu stronach ulicy, wzdłuż której szła. Cristina była młodą dziewczyną. Miała dwadzieścia cztery lata, ale dźwigała już spory bagaż życiowych doświadczeń. Właśnie to sprawiło, że tego dnia nie poszła z koleżankami na wielkie zakupy w ramach sezonowej wyprzedaży. Chciała być sama. Jej rówieśnicy nie mogli zrozumieć jak to jest, kiedy trzeba samemu być odpowiedzialnym za wszystko. Cztery lata wcześniej rodzice Cristiny nagle odeszli - zginęli w wypadku samochodowym. Od tego czasu sama zajęła się wychowaniem młodszego brata, który poprzedniego dnia skończył właśnie dwanaście lat i oświadczył, że woli spędzić urodziny z kolegami niż z nadopiekuńczą siostrą. Paolo był dobrym chłopcem, ale czasem potrafił kompletnie wyprowadzić ją z równowagi. Tak było i tym razem. Mocno się pokłócili.

Cristina każdego dnia parła odważnie do przodu, choć co jakiś czas napotykała na różne trudności. Tego dnia wydawały się one zbyt duże. Zupełnie nie wiedziała, jak sobie z tym wszystkim poradzić. Krążyła po Wiecznym Mieście jak statek, na którym zawiodły wszelkie przyrządy do nawigacji. Sama nie wiedziała jakim sposobem trafiła do Muzeum Watykańskiego, a potem w kaplicy Sykstyńskiej usiadła na ławce, żeby dać wytchnienie zmęczonym nogom. Długo przyglądała się scenom namalowanym przez Michała Anioła.

Pomyślała:

„Dziwne, że nigdy wcześniej tu nie byłam. Wychowałam się w tym mieście, ale przecież też nigdy mnie nie interesowały takie sprawy. Ciekawe, jaki On jest naprawdę?"

Nagle w głowie Cristiny pojawiły się myśli: „Jest Stwórcą: Ogarnia wszystko powołując do istnienia z nicości... Wszystko nagie i otwarte jest przed oczami Jego («Omnia nuda et aperta sunt ante oculos Eius»)...”

Pomyślała:

„Dziwne, pewnie jestem po prostu zmęczona...”

Wstała i poszła przed siebie. Trafiła wprost do bazyliki św. Piotra. Zobaczyła, że w jednej z kaplic świeci się czerwone światełko. Stoją konfesjonały. Nie była przekonana, czy tam właśnie powinna iść, ale coś jednak ją tam przyciągnęło, więc poszła. 
- Nie wiem, czy ksiądz to zrozumie, bo chyba nie potrafię dobrze wyrazić tego, co przeżywam. Tak naprawdę, to sama właściwie niewiele $\mathrm{z}$ tego rozumiem...

— Dobrze, że przyszłaś. Powiedz, jak mogę ci pomóc?

Pomyślał:

"Ach, jak dobrze to rozumiem. Pamiętam, kiedy i ja wpatrywałem się w słońce tonące w tafli chłodnego jeziora. Szukałem dalekiego wybrzeża ciszy. To było wtedy, kiedy próbowałem odnaleźć ją w sobie. I znalazłem w Przyjacielu, który wtedy do mnie przyszedł, kiedy inni odeszli i zostałem sam. Długo wpatrywałem się głębiej, i głębiej, i coraz mocniej nachylałem się w tym spojrzeniu. Wtedy odkryłem ten nurt, który objął mnie całego tak bezpowrotnie. Odkryłem to piękno, któremu chciałem cały oddać się bez reszty. W jednej chwili wszystko stało się takie jasne i takie proste. Siedziałem na brzegu jeziora, a On szedł ku mnie bez słowa i tym milczeniem trafiał wprost do serca."

Powiedział:

- Pójdź tam, przed Najświętszy Sakrament, wybierz sobie jedną z ławek, nie patrz na zegarek i spróbuj tam dłuższą chwilę po prostu tak trwać przed Nim. Spróbuj przez ten czas nie martwić się o to, co przyniesie jutrzejszy dzień. Później przyjdą też i kolejne dni, ale myśl tylko o tej jednej chwili, którą właśnie przeżywasz. Spróbuj otworzyć się na nią i dać się ogarnąć i objąć Jego miłości, której iskra jest wewnątrz ciebie ukryta. Jeśli Mu pozwolisz, to w Jego świetle zobaczysz te wszystkie cienie, które cię niepokoją. Jeśli pozwolisz, by On pochylił się nad tobą, to te cienie przestaną ci tak bardzo ciążyć. On doda ci sił i nadziei na dalszą drogęe

- Proszę księdza, proszę mi wybaczyć, ja nie wierzę, żeby to w czymś pomogło. Takie siedzenie w ławce. Nigdy tego nie mogłam zrozumieć. Wiem, że księża i zakonnice muszą, niektórzy ludzie też to robią, ale ja nigdy nie potrafiłam usiedzieć tam dłużej niż to było konieczne. Ja tego zupełnie nie czuję. Tej całej obecności. Ja nie słyszę żadnego głosu Boga.

— Zastanawiałaś się kiedyś czym stał się Bóg, żebyśmy mogli Go oglądać? Jak się uniżył. Zatrzymał się o krok od nicości. Dlatego czasem zdaje się nam, że całkiem zniknął w cieniu kłosów. Spróbuj uczyć się od Niego tego ukrycia. Nie mówię, że to jest proste, ale powiem ci z całą pewnością, że warto spróbować. Ja też często doświadczam tego, że im bardziej oczy wytężam, tym mniej widzę... A jednak nie rezygnuję i wtedy On zstępuje jakby na brzegi mojej duszy.

- Jak ksiądz tak o tym mówi, to wydaje się takie proste. I chce się spróbować. Boję się jednak, że później znów się zniechęcę...

Pomyślał:

„Pamiętam, kiedy mój smutek zmieszany z wieczorem napełnił mnie lękiem. To była dla mnie prawdziwa groza tamtego wieczoru i bałem się pozostać z nią sam na sam. Byłem pewnie wtedy mniej więcej w wieku tej dziewczyny..." 
- Nie mówię, że to jest proste. Takie trwanie wymaga często wiele odwagi, ale... opowiem ci taką historię. Kiedyś wydawało mi się, że człowiek jest jak liść na wietrze - taki słaby. Pomyślałem wtedy: cóż może taki liść? I wtedy zrozumiałem, że dusza ludzka nie jest jak liść. Dusza jest czymś o wiele większym i o wiele więcej może znieść. I ta myśl napełniła mnie otuchą i dała nadzieję.

- Ja często czuję się jak taki liść, który ledwo uwieszony jakiejś gałązki, szamocze się na wietrze...

- Wtedy właśnie pomyśl o Jezusie, który zawisł na krzyżu. Czy przez to nie stał nam się bardzo bliski?! Właśnie przez to stał się jeszcze bardziej naszym bratem.

- Nigdy tak o Nim nie pomyślałam. Właściwie, to w ogóle o Nim nie myślałam zbyt wiele. Ksiądz jest jakiś inny... Tak jakby ksiądz mnie znał... a to przecież niemożliwe!

— Pomyśl o tym, kiedy usiądziesz w tamtej ławce, że On zna cię jeszcze lepiej. Pomyślał:

„Proszę Cię, byś ją ukrywał w miejscu niedostępnym, w nurcie cichego podziwu lub w nocy posępnej...

Proszę Cię, byś ją osłaniał od tej strony, co zapada w mrok - a proszę Cię, byś ją odsłaniał ku tej stronie, co przykuwa wzrok..."

Cristina czuła, że za kratką konfesjonału ten dziwny ksiądz modli się za nią. Nie chciała przerywać tej modlitwy i tej ciszy, w której czuła moc, wielką życzliwość i nadzieję. Czuła, że często będzie wracać do tego konfesjonału, żeby znów nabrać tej mocy i nadziei. Zastanawiała się nad tym, że słaby głos wskazywał na sędziwy wiek kapłana, ale treść słów świadczyła o młodzieńczej bystrości umysłu. Czuła, że to spotkanie dobiega końca i żałowała, że niedługo będzie musiała od tej kratki konfesjonału odejść.

Zrobiła dokładnie to, co miała zrobić. Usiadła w ławce i wpatrywała się w jeden punkt. Patrzyła spojrzeniem dziecięcym skupionym w łagodnej białej Hostii. Nigdy wcześniej nie spędziła tyle czasu na modlitwie, ale też i teraz nie nazwałaby tego modlitwą. Raczej czymś w rodzaju poszukiwania wzajemności. I stało się tak, że tego dnia Cristina doświadczyła spotkania z Ojcem Niebieskim, który popatrzył na nią z niezmierną miłością. Później, kiedy wróciła do domu, odnalazła też właściwe słowa, by pojednać się z Paolem.

Jednak zanim wyszła z bazyliki św. Piotra, zobaczyła jeszcze coś. Do konfesjonału, od którego niedawno odeszła, podbiegł młody ksiądz. Był wyraźnie poruszony. Kiedy zobaczył, że spowiednik jest sam, delikatnie zwrócił się do niego tymi słowami:

- Proszę wybaczyć, ale wszyscy szukają ojca świętego i martwią się o Waszą Świątobliwość...

- Niepotrzebnie, przecież tu jestem bezpieczny. Czy można znaleźć lepsze miejsce? 
- Oczywiście...

— No, no, już dobrze. Pójdę. Wiem, że wiele spraw czeka i dać dłużej czekać po prostu nie wypada.

Cristina nie mogła uwierzyć własnym oczom i uszom. Ten starszy ksiądz, u którego przed chwilą się spowiadała, to był ni mniej ni więcej tylko sam papież. Skąd mogła wiedzieć... choć wydawało się, że nie sposób było się tego nie domyśleć. Przecież na co dzień nie miała czasu, żeby słuchać papieskich przemówień. Zresztą w telewizji mówił pełnym głosem, a w konfesjonale zaledwie szeptem.

Tego dnia postanowiła sobie mocno, że gdyby tak się zdarzyło, że kiedyś urodzi syna, to nada mu imię po tym papieżu. Tego dnia postanowiła sobie też równie mocno, że będzie wracać do tej ławki w bazylice św. Piotra i że będzie w niej siedzieć tak długo, aż nabierze nowych sił do podejmowania kolejnych życiowych wyzwań. Postanowiła sobie mocno, że nie pozwoli sobie na zniechęcenie. Poszła też do księgarni i znalazła kilka książek napisanych przez papieża. Przeczytała wiele $\mathrm{z}$ nich, jednak kiedy natrafiła na wiersz napisany w Krakowie tuż przed wybuchem wojny zadedykowany Emilii, Matce... Cristina nie mogła powstrzymać łez. Często wracała do tego tekstu wspominając własną mamę, a któregoś dnia wybierając się na cmentarz, zabrała ten wiersz ze sobą. Paolo zazwyczaj nie lubił chodzić na grób rodziców. Tym razem jednak jakoś dziwnie postanowił towarzyszyć siostrze. Kiedy wyciągnęła z kieszeni zbiorek poezji, zapytał: co tam masz? Odpowiedziała: eh, takie tam... Jednak kiedy koniecznie chciał zobaczyć, podała mu mówiąc: wiesz, to napisał nasz papież. Paolo zaczął głośno czytać: „Nad Twoją białą mogiłą białe kwitną życia kwiaty...”. Skomentował:

- Patrz Cristina, pisze o nas...

Tego dnia Paolo zmienił zdanie o ojcu świętym, a kiedy zaczął czytać poemat zatytułowany Matka, powiedział:

- Myślałem, że to jakiś oderwany od życia starzec. A tu, patrz - pisze o życiu.

Paola jednak zwłaszcza zachwyciła, a następnie zainspirowała Pieśn o słońcu niewyczerpanym. Długo zastanawiał się nad stwierdzeniem o tym, że dusza nie jest taka jak liść, a po latach, kiedy już został znanym malarzem, postanowił namalować serię szesnastu obrazów zatytułowanych Słońce i liść. Każdy z obrazów przedstawiał część poematu Karola Wojtyły. Kiedy udało mu się wreszcie ukończyć to niezwykłe dzieło, podczas uroczystości otwierających długo wyczekiwaną wystawę, powiedział:

- Dzisiaj będziecie mogli obejrzeć efekt długoletniej pracy pewnego malarza, ale jednocześnie zobaczycie to, co opisał dawno temu pewien poeta, dzięki któremu jesteśmy tutaj dzisiaj razem. Dlatego dla każdego z was mam pewien upominek - nie zapomnijcie zabrać ze sobą do domu tomiku wierszy Karola Wojtyły.

Tego samego dnia wieczorem zadzwonił do Paolo znajomy muzyk opowiadając mu, że kiedy wracał do domu autobusem, zaczął padać deszcz. Sięgnął wów- 
czas do tomiku wierszy Wojtyły i przeczytał: „Zatrzymaj przez chwilę wzrok na kroplach świeżego deszczu...”

- Paolo, czytałem ten wiersz i obserwowałem drobne kropelki na szybie. Pojawiały się nagle to tu to tam... Przyroda opisywała na szkle w nieznanym mi języku jakieś zawiłe historie. Pomyślałem, że mógłbym z tego ułożyć zupełnie nowy motyw muzyczny - każda kropla to dźwięk... Już zaczęły się układać w mojej głowie w całkiem ciekawą melodię, jeszcze chwila i... Kropelki zaczęły rozmazywać się w przeciągłe smugi - autobus ruszył. Jeszcze nie zdążyłem poznać tajemnicy tego dzieła zapisanego na szybie. Może jeszcze nie czas na to... Kiedy maszyna była już rozpędzona w nieznane, krew tętniła w żyłach, pomyślałem, że niby każdy wie dokąd tak pędzi...

Parę miesięcy później, Paolo odwiedził znajomego muzyka, który zagrał mu ciekawy motyw muzyczny i powiedział:

- To było jak objawienie. Już tak długo nie umiałem znaleźć właściwych dźwięków, a tamtego wieczoru coś się stało, odpuściła jakaś niewidzialna blokada i zacząłem pisać. To będzie musical. Chciałbym ci, Paolo podziękować, bo to wszystko dzięki tobie i temu tomikowi poezji, który mi dałeś.

Kompozytor napisał bardzo dobry musical, który cieszył się ogromnym zainteresowaniem publiczności. W wywiadach opowiadał zawsze o swojej podróży autobusem podczas deszczu oraz o tomiku poezji Karola Wojtyły, dzięki któremu odnalazł natchnienie i mógł stworzyć to piękne dzieło.

Czas pokazał, że choć przyszły różne dni w życiu Cristiny, wytrwała ona w swoich postanowieniach i pozostała wdzięczna temu niezwykłemu spowiednikowi, który tchnął w nią tego dnia tyle siły i nadziei. Często też wracała do ulubionego wiersza Dla towarzyszów drogi...

Jeśli szukasz owego miejsca, na którym zmagał się Jakub, nie wędruj do krain Arabii, nie szukaj na mapach potoku, bowiem znajdziesz o wiele bliżej ich ślad. Pozwól tylko: w perspektywie myśli niech zjawiają się światła przedmiotów, coraz ściślej związane myślą i w coraz prostszy kształt. Wówczas obraz się nie rozprasza, lecz ciąży. I na to bądź gotów, że masz w sobie ten obraz udźwignąć, że się cały zamieniasz w tę treść, której sprzyja cisza i samotność, samotność możliwa w człowieku, możliwa dlatego, bo od niej nie odrywa nikogo śmierć.

Jeżeli zaś nasze dni wypełniają uczynki zwyczajne, w których ciągle samo wnętrze czynu nieodstępny przesłania gest, to jednak żywimy tę pewność, że kiedyś gest ów odpadnie, a zostanie w uczynkach naszych tylko to, co naprawdę jest.

Kiedy czytała ten tekst, myślała o tym, z jakimi przeciwnościami musiał zmagać się jego autor. Próbowała wyobrazić sobie pracę w kamieniołomie na Zakrzówku, 
w solvayowskiej kotłowni w Borku Fałęckim, a potem w Nowej Hucie. Znajdowała jednak w lekturze tego tekstu pociechę i siłę do zmagania się z codziennymi przeciwnościami, jakie przynosiło życie. Zaczęła nawet zaglądać do Pisma Świętego, gdzie znalazła opis zmagania Jakuba z Bogiem. Stwierdziła, że skoro takie zmagania są opisane w Biblii, to swoje osobiste trudy może również przynosić do tej ławki kościele, gdzie w ciszy i samotności możliwe będzie ponowne odnalezienie właściwej treści swojego życia.

Któregoś razu Cristina jechała pociągiem. Wsiadła zdyszana kobieta z dużą torbą i małym chłopcem. Powiedziała, że jadą do Ośrodka dla bezdomnych... kto by się spodziewał. Mały bystrzak rozglądał się, żeby nie przegapić stacji. Matka smutna, wyraźnie przybita całą tą sytuacją, powiedziała, że gdyby nie to dziecko to całkiem by się załamała. Cristina opowiedziała jej o wierszu Dla towarzyszów drogi i ofiarowała zbiorek poezji Karola Wojtyły.

Kiedy wiele lat później Cristina opowiedziała swojemu mężowi o tamtym spotkaniu z ojcem świętym, ten na początku nie chciał uwierzyć. Gdy jednak uparcie zapewniała go i obstawała przy swoim, przyznał wreszcie, że widocznie musiało się to wydarzyć naprawdę. Zaproponował wówczas wspólną wyprawę do Polski, żeby mogła zobaczyć na własne oczy te miejsca, o których tyle czytała. Cristina była za taki pomysł bardzo wdzięczna. Głęboko przeżyła podróż do Polski, a po powrocie postanowiła opisać swoje doświadczenia w książce. Do dziś jednak nie zdecydowała się na opublikowanie tekstu, do którego często zagląda, który poprawia i uzupełnia o kolejne historie z życia swojej rodziny i innych znajomych osób.

Ostatnio jednak musiała więcej uwagi poświęcić sprawom rodzinnym. W zeszłym miesiącu urodziła bliźniaki. Razem z mężem uznali, że nie ma w tym przypadku i że obaj chłopcy otrzymają imiona osoby, której tak wiele zawdzięczają. Jeden został ochrzczony jako Giovanni, a drugi, ponieważ już jeden Paolo był w rodzinie, otrzymał imię Carlo. Cristina pomyślała, że trzeba będzie poczekać aż chłopcy dorosną i również dopiszą swoje rozdziały do jej książki. 


\section{Abstract \\ The Certain Confession}

The story and the figure of the main character were invented for the purpose of the narration which was to show a certain mechanism of transferring the potential both life and creative similar to the physical transfer of thermal energy present in the phenomenon of heat conduction. It is a known fact that John Paul II in St. Peter's Basilica personally confessed the faithful on Good Friday, and the penitents were random.

John Paul II's statements in the text are taken from Pieśn o Bogu ukrytym (The Song of the Hidden God) as well as Pieśn o stońcu niewyczerpanym (The Song of the Infinite Sun), and the reflections of the main character in the Sistine Chapel are taken from Tryptyk Rzymski (The Roman Triptych).

Keywords: Pope John Paul II, life potential, creative potential, poetry, confession 